Józef Kus

(Lublin)

\title{
Inwentarz rzeczy pozostałych po stolniku przemyskim Jerzym Wołodyjowskim z 1674 roku
}

ABSTRAKT: W księgach grodzkich grabowieckich, przechowywanych w Archiwum Państwowym w Lublinie, znajduje się rejestr rzeczy pozostałych po stolniku przemyskim Jerzym Wołodyjowskim, który był pierwowzorem Sienkiewiczowskiego „Małego Rycerza” - obrońcy Kamieńca Podolskiego w 1672 r. W artykule przedstawiono tradycję związaną z legendą pułkownika Wołodyjowskiego, podstawowe fakty z jego życia oraz okoliczności powstania inwentarza pośmiertnego, wykorzystanego w trakcie procesu przeciwko osobom, które bezprawnie zagarnęły nieruchomości zmarłego. Autor artykułu stwierdza w konkluzji, że autentyczny Wołodyjowski tylko pod pewnymi względami przypominał swój literacki, Sienkiewiczowski, portret. Był istotnie świetnym zagończykiem i zginął w Kamieńcu Podolskim, tak jak „pan Michał”, chociaż jego śmierć była przypadkowa. Był również pułkownikiem, lecz nie dowodził chorągwią laudańską. Nie był też najprawdopodobniej nigdy na Litwie, gdzie region etnograficzno-historyczny Lauda się znajdował. Artykuł zawiera edycję inwentarza sporządzonego po śmierci Jerzego Wołodyjowskiego.

sŁowa KLuczowe: Henryk Sienkiewicz, Jerzy Wołodyjowski, inwentarz pośmiertny, Podole, Kamieniec Podolski.

W księgach grodzkich grabowieckich, przechowywanych w Archiwum Państwowym w Lublinie, znajduje się protestacja Jakuba Wołodyjowskiego, brata zabitego w 1672 r. stolnika przemyskiego Jerzego Wołodyjowskiego (który był pierwowzorem Sienkiewiczowskiego „Małego Rycerza”), wniesiona przeciwko 
innym pretendentom do schedy po nieżyjącym obrońcy Kamieńca Podolskiego ${ }^{1}$. Jej częścią jest rejestr pozostałości po Jerzym Wołodyjowskim, bardzo ciekawy dokument, wiele mówiący o stanie majątkowym stolnika przemyskiego.

Prawdziwe losy „pana Michała” znamy przede wszystkim dzięki opublikowanej ponad 120 lat temu pracy Józefa Apolinarego Rollego, lekarza z zawodu i historyka z zamiłowania, piszącego pod pseudonimem Dr Antoni J. Miał on możliwość korzystania z archiwów prywatnych na Podolu (Archiwum Wołodyjowskich, Archiwum Makowieckich, Archiwum Wacława Raciborowskiego z Makowa pod Kamieńcem, Papiery rodziny Szaławów Świrskich)2 , dziś już być może zatraconych ${ }^{3}$. Tu należy sobie postawić pytanie: czy prace J. A. Rollego znane były Henrykowi Sienkiewiczowi? Juliusz Kijas dowiódł, że obaj literaci kontaktowali się listownie i H. Sienkiewicz znał rękopis rozprawki J. A. Rollego Zdrada kamieniecka. Nie sięgnął natomiast do prac J. A. Rollego o Wołodyjowskich i kobietach w oblężonym Kamieńcu, gdyż te ukazały się już po publikacji Pana Wołodyjowskiego. Nie korzystał Sienkiewicz również z archiwów rodzinnych Wołodyjowskich i Makowieckich ${ }^{4}$.

Ustalenia J. A. Rollego wykorzystali natomiast Marceli Kosman ${ }^{5}$ i Władysław Czapliński ${ }^{6}$, a ostatnio Piotr Borek ${ }^{7}$ i Marek Wagner ${ }^{8}$ oraz Zbigniew

1 Archiwum Państwowe w Lublinie (dalej: APL), Księgi grodzkie grabowieckie, Relacje (dalej: Kgg, Relacje), sygn. 93, s. 959-964.

2 Dr Antoni J. [J. A. Rolle], Państwo Wołodyjowscy, [w:] Sylwetki historyczne. Serya viII, Kraków 1892, s. 296-343.

3 Brak w Polsce dostępnych przewodników po ukraińskich archiwach terenowych jeszcze przed dwudziestu kilku laty był przyczyną upowszechnienia się przekonania, że szlacheckie archiwa z terenów historycznego Wołynia, Kijowszczyzny, Bracławszczyzny, Podola uległy całkowitej zagładzie. W rzeczywistości jednak władze sowieckie sporo akt rodowych, rodzinnych i gospodarczych, a także spuścizn po polskiej szlachcie zabezpieczyły. Być może ocalało także Archiwum Wołodyjowskich. Zob. artykuł: T. Ciesielski, Spuścizny rodzinne i archiwa majątkowo-gospodarcze polskiej szlachty w wybranych archiwach ukrainskich, [w:] Stan badań nad wielokulturowym dziedzictwem dawnej Rzeczypospolitej, t. 2, red. W. Walczak i K. Łopatecki, Białystok 2010, s. 291-305.

4 J. Kijas, Źródła historyczne Pana Wołodyjowskiego, „Pamiętnik Literacki”, R. 43, 1952, z. 3-4, s. 1137-1156.

5 M. Kosman, Państwo Wołodyjowscy, [w:] Na tropach bohaterów Trylogii, Warszawa 1966, s. $274 \mathrm{i} \mathrm{nn}$.

6 W. Czapliński, Pan Wołodyjowski, [w:] Glosa do Trylogii, Białystok 1999, s. 99-109.

7 P. Borek, Stolnik przemyski Jerzy Wołodyjowski w „Relacyi Kamieńca wziętego...” Stanisława Makowieckiego i ostatniej części Trylogii Henryka Sienkiewicza, „Rocznik Przemyski”, t. 45, 2008, nr 3, s. 77-92.

8 M. Wagner, Wołodyjowski Jerzy, [w:] Słownik biograficzny oficerów polskich drugiej połowy XVII wieku, Oświęcim 2013, s. 296. 
Hundert ${ }^{9}$. Na pracach tych znanych historyków opieram się w niniejszym studium.

Pochodził Jerzy Wołodyjowski z drobnej szlachty podolskiej, pieczętującej się herbem Korczak. Przyszedł na świat po 1620 r. Był synem Pawła, właściciela Nowosiółki oraz części Chodorowiec i Paniowiec Zielenieckich na Podolu, nieopodal Kamieńca. Nauki pobierał w Kamieńcu Podolskim pod opieką stryja gwardiana w klasztorze Franciszkanów. Do nauki nie przejawiał jednak zbytniej chęci i bardziej niż do książki ciągnęło go do szabli. Wcześnie znalazł się w wojsku, gdzie szybko zdobył rozgłos zagończyka. Co robił podczas powstania Chmielnickiego i potopu szwedzkiego, nie wiadomo. Prawdopodobnie walczył z Kozakami w czasie wznieconego przez nich powstania i uczestniczył w potyczkach z włóczącymi się po Podolu „kupami swawolnymi”. Po śmierci ojca osiadł na części wsi Paniowce Zielenieckie. W 1662 r. ożenił się z Krystyną z Jeziorkowskich (ok. 1620-1675/6), córką Walentego, wdową po trzech już mężach: Pawle Świrskim, Janie Kondrackim i Mikołaju Zaćwilichowskim. Wychodząc za mąż za Wołodyjowskiego wniosła mu w posagu znaczny majątek, m.in. drugą część Paniowic Zielenieckich. Miała wówczas ponad 40 lat i daleko jej było do powieściowego „hajduczka”. 15 III 1668 r. Wołodyjowski został stolnikiem przemyskim $^{10}$. Jak pisze J.A. Rolle „pod względem materyalnym nie znaczyło to nic, ale pod względem społecznym znaczyło już wiele: nie był zwykłym ziemianinem, jak wszyscy jego przodkowie, ale dygnitarzem wyborowym..."11.

W 1669 r. odkupił od Stefana Złotnickiego, chorążego halickiego, regiment piechoty węgierskiej i odtąd tytułował się pułkownikiem. W październiku $1671 \mathrm{r}$. udał się na czele 560 żołnierzy do Chreptiowa w celu zorganizowania placówki strażniczej. Tak więc, podobnie jak u Sienkiewicza, Wołodyjowski „za opryszkami chadzał i całe nieraz watahy kozackie rozpędzał”. Te walki rozsławiły jego imię. Dzięki protekcji hetmana Sobieskiego otrzymał w 1669 r. stanowisko rotmistrza w twierdzy kamienieckiej, do której został oddelegowany na zimę 1671-1672 ze stanicy w Chreptiowie. Jeszcze w 1667 r. Wołodyjowski otrzymał od króla Jana Kazimierza list przypowiedni na objęcie dwu chorągwi węgierskich w Kamieńcu, lecz w przeddzień ataku tureckiego - według ustaleń Zbigniewa Hunderta - był rotmistrzem tylko jednej chorągwi pieszej. Pod jego ko-

9 Z. Hundert, Garnizon wojskowy Kamieńca Podolskiego w latach 1667-1672 - zarys problematyki, „Saeculum Christianum”, t. 21, 2014, s. 141-153.

10 Urzędnicy województwa ruskiego XIV-XVIII wieku (ziemie halicka, lwowska, przemyska, sanocka). Spisy, oprac. K. Przyboś, Wrocław 1987, s. 243.

11 J. A. Rolle, op. cit., s. 309. 
mendą znalazło się ponadto 24 dragonów. Jednakże, konkluduje autor, Stanisław Makowiecki wspomina o pułku konnym pod dowództwem Wołodyjowskiego, a zatem minimum dwóch chorągwi, a także nazywa tę konnicę „wołoszą”. Zatem Wołodyjowski miał pod swoją komendą kilka jednostek z garnizonu kamienieckiego, "co zapewne uprawniało go do posługiwania się tytułem pułkownika”"12.

Gdy w 1672 r. wielka armia turecka ruszyła na Rzeczypospolitą, jedna z najpotężniejszych twierdz ówczesnej Rzeczpospolitej nie była w stanie oprzeć się długotrwałemu oblężeniu, do którego nie była przygotowana. Przewaga liczebna wojsk tureckich (100 000) nad obrońcami była olbrzymia. Sułtan zatrudniał znakomitych artylerzystów francuskich, posiadał nowoczesne działa i doborowych saperów, podczas gdy załoga twierdzy kamienieckiej liczyła ok. 1600 żołnierzy, z których tylko 200 stanowiło stałą załogę. Po ośmiu dniach obrony postanowiono się poddać. Decyzja o kapitulacji spotkała się z niezadowoleniem wielu żołnierzy i oficerów. Jednym z nich był Jerzy Wołodyjowski. Wedle współczesnych relacji miał powiedzieć, że woli zginąć, aniżeli widzieć wojska tureckie wchodzące do twierdzy. W czasie oblężenia pełnił faktyczną funkcję dowódcy załogi zamkowej (formalny dowódca, generał ziem podolskich Mikołaj Potocki, miał słabe pojęcie o służbie wojskowej). Warunki poddania były honorowe. Wojsko wraz z dobytkiem i rodzinami miało prawo opuścić twierdzę, a mieszkańców nie spotkało nic złego, pozostawiono im nawet wolność wyznania. W chwili, gdy polscy emisariusze wracali z warunkami, a Wołodyjowski przygotowywał wymarsz wojsk polskich, jedną z wież wstrząsnęła potężna eksplozja. Pan Jerzy, widząc wybuch i chcąc uskoczyć, poderwał konia, lecz w chwilę potem trafił go w głowę kartacz, który samoistnie, na skutek eksplozji, wypalił z działa, zabijając stolnika na miejscu.

Pisze o śmierci Jerzego Wołodyjowskiego pamiętnikarz Mikołaj Jemiołowski:

Był w Kamieńcu natenczas Jan Potocki, starosta i generał kamieniecki, był i biskup kamieniecki Lanckoroński, był i podkomorzy podolski Lanckoroński, było i inszej szlachty podolskiej przed nieprzyjacielem do kamienieckiej fortecy zbiegłej, w której nie było tylko cztery chorągwie pancerne, a piechoty 200, dział ze 400, a puszkarzów (o czemem od człeka wiary godnego słyszał) tylko cztery, prochu i kul było potrosze, ale tymi na zamku starym Wołodyjowski zawiadywał, i potem

12 Z. Hundert, op. cit., s. $143-144,148-149$. 
postrzegłszy niebezpieczeństwo tymiż prochami, czy umyślnie, czyli z trafunku, tenże zamek już w oblężeniu będący wysadził i sam tam poleg1 ${ }^{13}$.

Tak zaś ten epizod opisuje szwagier poległego Wołodyjowskiego, Stanisław Makowiecki (mąż Anny Wołodyjowskiej), uczestnik obrony Kamieńca:

Bo, gdy te prochy ogniami rzucili, Po wszystkim zamku działa zapalili,

Co to w pośrodku stali z kartaczami, Tamo ich byli postawiali sami.

Gdy zajrzał ogień ten Wołodyjowski, Chciał się na koniec za wał umknąć troszki,

A wtym kartacze, będąc zapalone, Precz mu wyrwali głowy tylną stronę.

Kość wszystka z mózgiem, nie wiem, gdzie się działa, Tylko twarz z okiem jednym się została.

Tam poległ wtenczas snem twardo uśpiony, Chyba w dzień sądny będzie obudzony ${ }^{14}$.

Okoliczności wybuchu nie są więc jasne. Został spowodowany bądź przez oficera artylerii fortecznej Hejkinga (pierwowzór Ketlinga), bądź też nastąpił przypadkowo $^{15}$. Wybuch 200 beczek prochu spowodował zniszczenie zamku górnego, zabijając przy tym od 500 do 800 ludzi, głównie komputowych Kozaków.

Zwłoki Jerzego Wołodyjowskiego, za zgodą Turków, złożono w podziemiach kościoła Franciszkanów w Kamieńcu Podolskim. Msze za jego duszę były w Kamieńcu odprawiane jeszcze w XIX w. Żony Wołodyjowskiego Krystyny, pierwowzoru Sienkiewiczowskiej Basi, w czasie oblężenia twierdzy nie było w Kamieńcu, przebywała w tym czasie na Litwie. Po śmierci Wołodyjowskiego wyszła piąty raz za mąż, za pisarza ziemskiego podolskiego Łukasza Franciszka Dziewanowskiego.

13 Pamiętnik Mikołaja Jemiołowskiego, towarzysza lekkiej chorągwi, ziemianina województwa bełzkiego..., wyd. A. Bielowski, Lwów 1850, s. 222.

14 S. Makowiecki, Relacyja Kamieńca wziętego przez Turków w roku 1672, oprac. P. Borek, Kraków 2008, s. 157.

15 Tak podaje Stanisław Makowiecki (ibidem, s. 162). Por. A. Przyboś, Hejking, [w:] Polski słownik biograficzny, t. 9, red. K. Lepszy, Wrocław 1961-1962, s. 351-352. 
Szwagier Jerzego Wołodyjowskiego, Stanisław Makowiecki, przyczynił się do utrwalenia sławy mężnego rycerza, którego portret skreślił następująco:

I byłby nie człek, by go nie żałował,

Tego człowieka kto jeno widował.

Umiał ten we wszem każdemu dogodzić,

W każdym terminie z każdym mógł się zgodzić.

Wojenne trudy nic mu nie szkadzały,

Ale go sławy dobrej nabawiały.

Gromił opryszków, gromił i Kozaków,

I z krymskiej ordy wybornych junaków

Oddawał z swych rąk wielkiemu wodzowi.

Lub kto nie wiedział, sława o nim powie,

Jako ten człowiek stawał w każdym razie,

Nie żałując się, choć był w zdrowia skazie.

Szczerze w terminach wszech się nadstawował,

I na sejmikach, kiedy więc wotował,

Prawdę mówiący brnął tak środkiem drogi,

Przeciwnym ludziom bywał zawsze srogi.

W konwersacyji wchodził z każdym szczerze,

Zgodę z miłością zachowując w mierze ${ }^{16}$.

Wojnę z Turcją zakończył niekorzystny dla Polski traktat w Buczaczu, na mocy którego oddano Turcji Podole i część Ukrainy. Upadek Kamieńca zapoczątkował wychodźstwo szlachty polskiej z Podola. Egzulanci (bo tak ich zwano) pozbawieni zostali majątków, a niekiedy środków do życia. Należeli do nich również niektórzy spadkobiercy Jerzego Wołodyjowskiego, a z racji tego, że okupacja turecka przerwała funkcjonowanie podolskich sądów szlacheckich, praw swoich dochodzili w innych grodach Rzeczypospolitej, m.in. w Grabowcu w województwie bełskim. W pięć lat po śmierci „Hektora Kamienieckiego” jego starszy brat, Jakub Wołodyjowski, tam właśnie złożył wspomnianą na wstępie protestację przeciwko chorążynie nadwornej koronnej Świętosławie Dunin Rajeckiej Prażmowskiej (wdowie po staroście generalnym podolskim Mikołaju Potockim), Łukaszowi Franciszkowi Dziewanowskiemu, pisarzowi ziemskiemu podolskiemu (wdowcowi po Krystynie z Jeziorkowskich Wołodyjowskiej) oraz

16 S. Makowiecki, op. cit., s. 160. 
Krzysztofowi Dzierżkowi (wdowcowi po Helenie, siostrze Krystyny Wołodyjowskiej) i jego synom, Remigianowi i Jackowi, o nieprawne zagarnięcie bonis tam mobilibus, quam immobilibus in auro, argento, clenodiis, vestibus vestimentis, equis edendiis, summis paratis tum et immobilibus seorsino regestro specificandi $i^{17}$. Do spadku po Jerzym i Krystynie (zmarłej ok. 1676 r.) Wołodyjowskich pretendowali również Maria Matczyńska - druga siostra Krystyny, kapituła kamieniecka, franciszkanie kamienieccy, spadkobiercy pierwszych trzech mężów pani Krystyny.

Jakub Wołodyjowski występował nie tylko w swoim imieniu, lecz także siostry Anny, żony znanego już nam stolnika latyczowskiego, Stanisława Makowieckiego. Powód załączył do protestu rejestr rzeczy pozostałych po nieboszczyku (spisany przez siebie 11 X 1674 r.), „które zostały przy nieboszczce jejmości paniej Krystynie Wołhodyiowskiej quarti nuptis małżonce nieboszczykowskiej"18.

Inwentarze, a wśród nich inwentarze pośmiertne należą obok testamentów do najczęściej sporządzanych dokumentów publicznych. Mają one szczególne znaczenie w badaniach nad kulturą materialną, życiem codziennym, historią mentalności w czasach nowożytnych. W ostatnich latach ukazało się wiele prac opartych na inwentarzach oraz edycji źródłowych tekstów inwentarzy pośmiertnych zarówno szlachty, jak i mieszczan ${ }^{19}$.

${ }^{17}$ Kgg, Relacje, sygn. 93, s. 962-963: „(...) dóbr tak ruchomych, jak i nieruchomych w złocie, srebrze, klejnotach, sukniach, odzieży, koniach, sumach w gotówce a także i nieruchomościach, osobnym rejestrem wyszczególnionych (...)”.

18 Oblaty należało dokonać we właściwym terytorialnie sądzie grodzkim, jednakże ten warunek nie był przestrzegany rygorystycznie i przypadki wnoszenia dokumentów do ksiąg tam, gdzie było zainteresowanemu wygodnie, były na porządku dziennym. W tym przypadku na przeszkodzie stanęła okupacja Podola.

${ }^{19}$ Na przykład: A. Pośpiech, Pułapka oczywistości. Pośmiertne spisy ruchomości szlachty wielkopolskiej z XVII wieku, Warszawa 1992, s. 7; A. Klonder, Wszystka spuścizna w Bogu spoczywającego. Majątek ruchomy zwykłych mieszkańców Elblaga i Gdańska w XVII wieku, Warszawa 2000, s. 9-10; tenże, Mienie godne szlachcica i mieszczanina w krajach Europy Środkowej w XVII wieku, „Kwartalnik Historii Kultury Materialnej” (dalej: KHKM), t. 49, 2001, nr 1-2, s. 81-88; K. Justyniarska-Chojak, Testamenty i inwentarze pośmiertne z ksiąg miejskich województwa sandomierskiego (XVI-XVIII wiek), Kielce 2010, s. 92; M. Gadocha, Testamenty i inwentarz Jadwigi i Marcina Mitkiewiczów - przyczynek do dziejów mieszczaństwa krakowskiego, „Rocznik Lubelskiego Towarzystwa Genealogicznego”, t. 3, 2011, s. 99-100; E. Kizik, Gdański inwentarz pośmiertny toruńskiego drukarza Johanna Christopha Jungmanna z 1778 roku, „Zapiski Historyczne", t. 80, 2015, s. 169-178; J. Pielas, Inwentarze pośmiertne ruchomości szlachty sandomierskiej z XVII-XVIII wieku - perspektywy i problemy metodologiczne przygotowywanej edycji źródłowej, KHKM, t. 63, 2015, nr 4, s. 629-630. 
Inwentarze spisywano zazwyczaj według pewnych reguł. Wskazówki, jak należy inwentaryzować mienie, można znaleźć w dziełach niemieckich znawców prawa z początku XVII w., np. u Adama Volckmanna czy Johanna Rudolpha Sattlera. Na gruncie polskim rady dotyczące tworzenia inwentarzy sformułował Bartłomiej Groicki, który wskazywał, że w inwentarzu powinna być zapisana każda rzecz z gospodarstwa, szczególnie zaś majątek po zmarłych, nieruchomy i ruchomy, z domu i obejścia ${ }^{20}$. Zgodnie z polskim prawem inwentarz musiał być przygotowany do trzydziestego dnia po śmierci zmarłego ${ }^{21}$. W przypadku inwentarza Jerzego Wołodyjowskiego termin ten nie został dotrzymany. Inicjatorami spisania rejestru mienia po zmarłym byli najczęściej jego krewni, zainteresowani podziałem spadku. Dla uwierzytelnienia, podobnie jak w przypadku testamentów, był on wpisywany do ksiąg sądowych. Prezentowany inwentarz, sporządzony przez brata zmarłego, Jakuba Wołodyjowskiego, tenże przedłożył do oblaty w grodzie grabowieckim w sobotę przed świętem św. Walentyna Męczennika (13 II) w roku 1677.

Wróćmy zatem do „naszego” dokumentu. Spisujący inwentarz Jakub Wołodyjowski przede wszystkim skupił się na ochędóstwie, czyli ubiorach. Siedemnastowieczne archiwa podają, że kontusze szyto głównie z sukna, a te dla możnych - ze szlachetniejszych tkanin, do których wówczas zaliczano atłas i aksamit. Spis po Jerzym Wołodyjowskim świadczy o upodobaniu do ubioru polskiego i zamożności nieboszczyka. W garderobie stolnika pośród 11 sztuk odzieży znajdowało się pięć kontuszy, m.in. niezwykle reprezentacyjny kontusz szkarłatny, ozdobiony guzami aspisowymi oprawionymi w złoto i podszyty pupkami. Dużą wartość musiał prezentować także kontusz aksamitny, szkarłatny rysiami podszyty. Inwentarz wymienia też kontusz koralowy królikami podszyty oraz dwa kontusze letnie bez futrzanych podszyć, oba aksamitne. Wśród pozostałych ubiorów znalazły się: jupka czarna aksamitna popielicami podszyta, delia ciemnozielona podszyta grzbietami lisimi, żupan atłasowy szkarłatny w paski srebrne. Jest i kaftan atłasowy marcepanowy, „w którym go zabito”. W spisie wzmiankowane są również dwa płaszcze, sześć czapek, wśród których najwyżej cenione były aksamitne, obszyte sobolami. Nadto stolnik przemyski

${ }^{20}$ M. Gadocha, op. cit., s. 99-100; K. Justyniarska-Chojak, Taxatio rerum olim... - szesnastowieczne inwentarze pośmiertne z ksiag miejskich województwa sandomierskiego, KHKM, t. 63, 2015, nr 1, s. 41-42.

${ }^{21}$ B. Groicki, Porządek sądów i spraw miejskich prawa majdeburskiego w Koronie Polskiej, wyd. K. Koranyi, Warszawa 1953, s. 175; tenże, Obrona sierot i wdów, wyd. J. Sawicki, Warszawa 1958, s. 56. 
posiadał pewien zapas sukna (koralowego i różowego francuskiego, turkusowego i zielonego paklaku oraz falendyszu ciemnozielonego) na nową odzież i aksamitu na czapkę. Lubił zatem Jerzy Wołodyjowski się stroić.

$\mathrm{Na}$ drugim miejscu inwentarza, jak na człowieka „wojennego” przystało, wymieniono broń, lecz wyliczanie rynsztunku zakończono dopiero w dalszej części dokumentu - po towarach do sprzedaży, pościeli, gotówce, bydle, koniach i powozach. W sumie nieboszczyk pozostawił 19 sztuk broni palnej, obuch, buzdygan i kałkan oraz pancerz (najprawdopodobniej kolczugę) z karwaszami i części rzędu końskiego.

Posiadał Jerzy Wołodyjowski pięć koni pod siodło, w tym tureckiego wartości 600 złp, jednego konia roboczego i trzy cugi. Do celów podróżnych używał karocy, kolasy i wozu skarbnego. Ruszając „w pole”, zabierał zapewne namiot „o trzech drągach” wartości 500 złp.

Był nie tylko urodzonym żołnierzem, potrafił także dobrze gospodarować na włościach swoich i żony - w miasteczku Szatawie i na siedmiu wsiach (Paniowce Zielenieckie, Błyszczanówka, Słobudka Michałowska alias Swistówka, Stupińce, Werbka, Przewrocie, Zielone Łąki), o czym świadczą spore dochody uzyskiwane ze sprzedaży zboża i produktów mlecznych, a zapewne również wołów, z hodowli których słynęło Podole. Do tego dochodziły: dwie części Zieleńca, części w Chodorowcach i dzierżawa wsi Sokół (wspólna z bratem).

Inwentarz nie odzwierciedla pełnego stanu posiadania stolnika przemyskiego. Nie wymieniono w nim na przykład kosztowności wycenionych na 50000 złp, które były spisane w osobnym rejestrze (o czym wspomniano wyżej). Nie są też uwzględnione wszystkie dobra ziemskie, z których czerpał profity. Skądinąd wiadomo, że w 1669 r. król Michał Korybut Wiśniowiecki zezwolił wojewodzie ruskiemu Stanisławowi Jabłonowskiemu na ustąpienia prawa dożywocia na rzecz Jerzego i Krystyny Wołodyjowskich na wsiach Zwiniec, Wołkowce, Babińce, Łatkowce, Trupczyn i w miasteczku Zwinigród ${ }^{22}$. Jak widać, nieboszczyk był człowiekiem majętnym, obok nieruchomości ziemskich, klejnotów, „gotowizny” posiadał duże stada bydła, konie, zaprzęgi i cugi, ogółem oceniane przez spadkobierców na przeszło 100000 złp. To sytuowało go wśród średniozamożnej szlachty.

Autentyczny Wołodyjowski tylko pod pewnymi względami przypominał swój literacki Sienkiewiczowski portret. Był istotnie świetnym zagończykiem

${ }^{22}$ Akta grodzkie i ziemskie z czasów Rzeczypospolitej Polskiej z archiwum tak zwanego bernardyńskiego we Lwowie..., t. 10, Spis oblat zawartych w aktach grodu i ziemstwa lwowskiego, oprac. O. Pietruski i X. Liske, Lwów 1884, s. 307, nr 5121. 
i rzeczywiście zginął w Kamieńcu, tak jak „pan Michał”, chociaż jego śmierć była przypadkowa. Był również pułkownikiem, lecz nie dowodził chorągwią laudańską. Nie był też najprawdopodobniej nigdy na Litwie, gdzie region etnograficzno-historyczny Lauda się znajdował. A czy był „szermierzem niezrównanym", nie wiemy.

Spór o schedę po Jerzym Wołodyjowskim trwał jeszcze trzy lata i przechodził przez różne instancje. $\mathrm{W}$ trakcie postępowania spadkowego dochodziło do aktów bezprawia ze strony Dzierżków. W 1677 r. najechali oni dwory Świętosławy Dunin Rajeckiej Prażmowskiej w Uchańce w starostwie dubieńskim i Łukasza Franciszka Dziewanowskiego pod Dubnem, ograbiając je doszczętnie ${ }^{23}$. Doszło nawet do zbrodni. W $1678 \mathrm{r}$. sąd lubelski nakazał przywiezienie wszystkich pozostałości po pięciokrotnej wdowie. Kiedy Dziewanowski wraz z Matczyńską wjeżdżali do Lublina, prowadząc kilkanaście wozów ze spuścizną po Krystynie, napadli na nich na ulicy Kowalskiej dwaj Dzierżkowie. Zagarnęli cały majątek po zmarłej, mordując przy tym sześciu ludzi. „Sprawa tedy kryminalna - pisze J. A. Rolle - zatem wieża i grzywny na winnych..."24. Sprawa zakończyła się w Trybunale Koronnym Lubelskim, który rozpatrzył ją dopiero w 1680 r. Pomijam tu dość szczegółowe postanowienie trybunalskie, dotyczące spadku po Wołodyjowskich, zainteresowanych odsyłając do pracy J. A. Rollego.

Rejestr pozostałości po Jerzym Wołodyjowskim był już publikowany ${ }^{25}$. Edycja rzeczonego inwentarza pozostawia jednak wiele do życzenia. W samym tylko tytule autor publikacji nazywa Jerzego Wołodyjowskiego pułkownikiem chorągwi laudańskiej, co jest widocznym wpływem lektury Trylogii Sienkiewicza, i datuje dokument na 1672 r. W tekście inwentarza kilka wyrazów jest błędnie odczytanych ${ }^{26}$, dziwne są też definicje niektórych terminów staropolskich ${ }^{27}$. Nie

${ }^{23}$ Kgg, Relacje, sygn. 93, s. 992-994.

24 J. A. Rolle, Państwo Wołodyjowscy, s. 339-340.

${ }_{25}$ S. Życiński, Inwentarz pozostałości po Jerzym Wołhodyjowskim pułkowniku choragwi laudańskiej z roku 1672, „Zeszyty Naukowe Muzeum Wojska w Białymstoku”, 1998, z. 12, s. 159-161.

${ }^{26}$ Na przykład: „sukna (...) po klaku” chociaż wcześniej podano prawidłowo „paklaku”, „pościel nt. odzienska” zamiast „młodzieńska”, „zań iego we Wrocławiu” zamiast „zań we Wrocławiu”, „zaś iego” zamiast „zań”, „na Paniowie” zamiast „na Paniowce”, „na Makijowie” zamiast „na Malejowce”, „Pana Gnata” zamiast „pana Generała” (w tekście zapisano skrótem Gnła, chodzi tu o Mikołaja Potockiego, generała ziem podolskich); przy wyliczaniu praw na różne dobra pominięty został Szatków.

${ }^{27}$ Ot, choćby: „karwasze - naramienniki metalowe”, „pieniądze rogowe - pieniądze bite ze srebra rogowego (ebonit i stopiony chlorek srebra)”, „szturmak - mocny hełm przeznaczony do ataku”. Tu należy się wyjaśnienie, iż: karwasze stanowiły ochronę przedramion, „pieniądze ro- 
znajdujemy natomiast wyjaśnień paru terminów, które tego wymagały. Zabrakło wreszcie omówienia okoliczności spisania inwentarza i jego wpisu do ksiąg sądowych. Wszystko to upoważnia nas do ponownego wydania tego ciekawego źródła historycznego. Inwentarz ten nie był znany J. A. Rollemu, a przynajmniej nic on o nim nie wspomina.

W publikowanym poniżej tekście pominięto samą protestację, prezentując tylko oblatowany do ksiąg grodzkich inwentarz pośmiertny Jerzego Wołodyjowskiego. Edycję tekstu dokumentu przygotowano na podstawie instrukcji wydawniczej dla źródeł od XVI do połowy XIX w. pod redakcją Kazimierza Lepszego, opracowaną w 1953 r. $^{28}$

Aby ułatwić lekturę, w inwentarzu ujednolicono i poprawiono pisownię (np. axamitny - na aksamitny, rumak i romak - na rumak, czaprag - na czaprak, buzdigan - na buzdygan), wprowadzono podział na akapity oraz interpunkcję. Przyjęto pisownię nazwiska Wołhodyiowski/Wołhodyiowska, gdyż taka w zasadzie w dokumencie występuje. Raz tylko użyto formy Wolodyiowscy Wołodyiowskich protestatio. Zachowano również oryginalną formę wyrazów: hatłasowy, hawtowany, usarski, jako charakterystyczną dla XVII w. Terminy staropolskie zostały wyjaśnione w przypisach pod tekstem źródłowym na podstawie publikacji: Józefa Szymańskiego ${ }^{29}$, Ireny Turnau ${ }^{30}$, Zuzanny Sawickiej ${ }^{31}$, Adama Dylewskiego ${ }^{32}$, Włodzimierza Kwaśniewicza ${ }^{33}$, encyklopedii staropolskich $^{34}$ i słowników języka polskiego ${ }^{35}$.

gowe" to opłata pobierana przez dziedziców za prawo wypasu bydła rogatego na ich ziemiach, zaś „szturmak” to nie tylko hełm, lecz i rodzaj broni palnej, i w tym drugim znaczeniu został użyty. Trudno bowiem wyobrazić sobie hełm z zamkiem kołowym, w dodatku „gwintowy” czyli gwintowany.

${ }^{28}$ Instrukcja wydawnicza dla źródeł historycznych od XVI do połowy XIX wieku, red. K. Lepszy, Wrocław 1953.

${ }^{29}$ J. Szymański, Nauki pomocnicze historii, Warszawa 1983.

${ }^{30}$ I. Turnau, Słownik ubiorów. Tkaniny, wyroby pozatkackie, skóry, broń i klejnoty oraz barwy znane w Polsce od średniowiecza do początku XIX w., Warszawa 1999.

31 Z. Sawicka, Słowniczek, [w:] Koń w życiu szlachty w XVI-XVIII w., Toruń 2004.

32 A. Dylewski, Historia pieniądza na ziemiach polskich, Warszawa 2011.

${ }^{33}$ W. Kwaśniewicz, Encyklopedia dawnej broni i uzbrojenia ochronnego, Warszawa 2017.

${ }_{34}$ Z. Gloger, Encyklopedia staropolska ilustrowana, t. 1-4, Warszawa 1900-1903; A. Brückner, Encyklopedia staropolska, t. 1-2, Warszawa 1939.

${ }^{35}$ Stownik języka polskiego, oprac. S. B. Linde, t. 1-4, Warszawa 1807-1814; Stownik staropolski, red. K. Nitsch, S. Urbańczyk, t. 1-11, Warszawa 1953-1995. 


\section{Summary}

\section{The 1674 Inventory the Belongings Left by Przemyśl Pantler Jerzy Wołodyjowski}

The register of things left by Przemyśl Pantler (Steward) Jerzy Wołodyjowski, who was a model for Sienkiewicz's "Small Knight" - the defender of Kamieniec Podolski in 1672 - can be found in the Grabowiec municipal records, which are kept in the State Archives in Lublin. The article presents the tradition connected with the legend of Colonel Wołodyjowski, basic facts from his life, and the circumstances of the compilation of the posthumous inventory used during the lawsuit against persons who illegally seized the real estates of the deceased. The author of the article concludes that the real Wołodyjowski resembled his literary, Sienkiewicz-created image only in some respects. He was indeed an excellent soldier and was killed in Kamieniec Podolski (like Michał Wołodyjowski, his book counterpart) but his death was an accidental one. He also was a colonel but he was not in charge of the Lauda cavalry company. He had probably never been to Lithuania, where this ethnographic-historical region Lauda (Liaude) was situated.

The article contains the edition of the inventory made after the death of Jerzy Wołodyjowski.

KEYWORDS: Henryk Sienkiewicz, Jerzy Wołodyjowski, posthumous inventory, Podolia, Kamieniec Podolski. 


\section{Tekst źródłowy}

Or.: Archiwum Państwowe w Lublinie, Księgi grodzkie grabowieckie, Relacje, sygn. 93, s. 959-964.

[s. 962] Regestr rzeczy pozostałych po nieboszczyku świętej pamięci imci panu Wołhodyiowskim stolniku przemyskim rotmistrzu Jego Królewskiej Mości, które zostały przy nieboszczce jejmości paniej Krystynie Wołhodyiowskiej quarti nuptis małżonce nieboszczykowskiej.

Naprzód ochędóstwo: kontus a aksamitny szkarłatny rysiami podszyty, kontusz aksamitny karmazynowy letni, kontusz szkarłatny pupkamib podszyty z guzami aspisowemi we złoto oprawnemi, kontusz zielony aksamitny letni, kontusz koralowy królikami podszyty, jupkac czarna aksamitna popielicami podszyta, delia $^{\mathrm{d}}$ ciemnozielona grzbietami podszyta lisiemi, żupan ${ }^{\mathrm{e}}$ hatłasowy szkarłatny w paski srebrne, kaftan hatłasowy marcypanowy ${ }^{\mathrm{f}}$, w którym go zabito [podkr. moje], hatłasu ceglastego na żupan łokci dwanaście, czapka aksamitna szkarłatna z sobolem, czapka szkarłatna z sobolem, czapka półgranatnia ciemnozielona z sobolem, czapka ciemnozielona z lisiemi wyłogami, czapka powszednia podróżna ciemnozielona, płaszcz falendyszowyg oliwkowy, płaszcz tuzinkowy ${ }^{\mathrm{h}}$ stary, sukna koralowego francuskiego łokci octo, sukna różowego francuskiego łokci dziesięć, sukna w sztukach turkusowego paklakui łokci trzydzieści i siedm, sukna zielonego paklaku łokci szesnaście, sukna falendyszu ciemnozielonego łokci pięć, czapka aksamitna niepodszyta, aksamitu na czapkę łokci półtora.

a Kontusz - szata wierzchnia, z typowymi tzw. wylotami, czyli rozciętymi od pachy do łokci rękawami, które albo luźno zwisały, albo, odrzucone do tyłu, odsłaniały żupan. Był to charakterystyczny element stroju polskiej szlachty $w$ XVII $i$ XVIII $w$.

b Pupka-skóra futerkowa z brzucha zwierzat.

c Jupka - wierzchnie okrycie kobiece, rzadko męskie.

d Delia - okrycie męskie podbite futrem.

e Żupan - dluga szata męska, przyjęta w Polsce w XVI w. z mody węgierskiej. Dopasowany w górnej części, powyżej linii bioder, luźny i obszerny dołem, zapinany był na pionowy szereg drobnych guzów, z rękawami szerokimi i bufiastymi od ramion do łokci, opiętymi w miejscu przedramion. Noszony w XVI w. jako szata wierzchnia, a od połowy XVII w. pod kontuszem.

f Marcepanowy-kolor marcepanu, biały o chłodnym szklanym odcieniu, beżowo-piaskowy, złota$w y$.

g Falendysz-gatunek wysokiej jakości sukna angielskiego i holenderskiego.

h Tuzinek - grube sukno krajowe średniego gatunku, używane do pokrycia zimowych okryć wierzchnich.

i Paklak-grube sukno krajowe, używane głównie na zimowe okrycia męskie. 
Pistoletów krzosowych ${ }^{\mathrm{a}}$ par dwie, karwasze ${ }^{\mathrm{b}}$ oprawne i łapkic ${ }^{\mathrm{c}}$, pancerz ${ }^{\mathrm{d}}-\mathrm{zan}$ sto czerwonych złotych ${ }^{\mathrm{e}}, \mathrm{kałkan}^{\mathrm{f}}$, obuch ${ }^{\mathrm{g}}$ oprawny, buzdygan ${ }^{\mathrm{h}}$ wielki, siedzenie ${ }^{\mathrm{i}}$ ciemnozielone bogato hawtowane.

Miodu przaśnego ${ }^{j}$ półbeczków ${ }^{\mathrm{k}}$ dwanaście, [s. 963] na te uczyniłem targ z Żydem arendarzem czarnokozińskim po lewkowych ${ }^{1}$ piętnastu, saletry beczek dwie, kamieni ${ }^{\mathrm{m}}$ sto sześćdziesiąt.

Pościel młodzieńska, materac hatłasowy karmazynowy, wał i poduszki dwie aksamitne, obicia hatłasowego $\mathrm{w}$ paski bret ${ }^{\mathrm{n}}$ błękitny, bret zielony sztuk czterdzieści.

Talerów lewkowych sto, czerwonych złotych w szkatule tysiąc $\mathrm{w}$ różnych portugałach ${ }^{\circ}$.

Zygarek pektoralikp - zań we Wrocławiu talerów czterdzieści.

a Pistolet krzosowy - pistolet z zamkiem krzosowym (kołowym), w którym zapalenie prochu następuje od iskier powstałych przez pocieranie obracajacego się karbowanego koła o piryt zamocowany w szczękach kurka.

$b$ Karwasze - metalowa ochrona przedramion, o proweniencji wschodniej (Turcja, kraje Azji Mniejszej); charakterystyczny element uzbrojenia ochronnego dla jazdy pancernej.

c Łapki-osłona palców dłoni.

d Pancerz (inaczej kolczuga) - koszulka spleciona z kółek żelaznych; kolczugi używane w Polsce $w$ XVII w. byly wykonane najczęściej z ogniw $z$ drutu spłaszczonego, o różnym sposobie łączenia (nitowane jednym nitem, na przemian: nitowanych $i$ sztancowanych lub nitowanych $i$ zgrzewanych).

e Czerwony złoty - dukat, moneta złota, równowartość w tym czasie 6 złotych polskich stanowiących jednostkę obrachunkowa.

f Kałkan - lekka, okrąła, wydatnie wypukła tarcza, o pochodzeniu wschodnim (turecko-perskim oraz tatarskim); w Polsce używana zazwyczaj przez jazdę, najpopularniejsza w XVI i XVII w.

g Obuch - rodzaj broni białej w kształcie młotka, mającego po przeciwległej stronie zawinięty $w$ dół dziób; stosowany od XVI do XVIII w. przez szlachtę polską, często posiadał drzewce dtugości $80-100 \mathrm{~cm}$ i byt noszony $w$ formie laski.

h Buzdygan - broń obuchowa pochodzenia wschodniego, metalowa głowica (zbudowana $z$ piór promieniście rozchodzących się od drzewca) osadzona na trzonku o dlugości ok. $60 \mathrm{~cm}$. W Polsce od XVI do XVIII w. stanowił oznakę władzy oficerskiej w kawalerii narodowego autoramentu: rotmistrzów, putkowników, poruczników i chorążych.

i Siedzenie-zapewne siodło.

j Miód przaśny - nieprzetworzony (patoka).

k Półbeczek - staropolska miara pojemności płynów, ok. 7o l. Była zróżnicowana w zależności od regionu.

1 Lewkowy - talar niderlandzki. Nazwa pochodzi od lwa umieszczonego na rewersie, zajmującego cate środkowe pole monety.

m Kamień - staropolska jednostka wagowa w systemie funta, równa $12 \mathrm{~kg}$ i $960 \mathrm{~g}$.

n Bret-(bryt) pas tkaniny.

- Portugat - potoczna nazwa złotej monety wielodukatowej, bitej w Europie w XVI i XVII w. Monety te stużyly przede wszystkim $w$ celach reprezentacyjnych, dekoracyjnych, jako upominki i pamiątki.

p Pektoralik-mały, ozdobny zegarek na łańcuszku, noszony dawniej w kieszonce na piersiach. 
Pieniędzy rogowych ${ }^{\mathrm{a}}$ ze Zwiniacznej i innych wsiów złotych ${ }^{\mathrm{b}}$ tysiąc dwieście. Bydła sztuk sto, stada sztuk sześćdziesiąt.

Koń turecki karyc - za niego złotych sześćset, koń rumak tarantowatye - zań talerów sto, bachmat ${ }^{f}$ gniady ${ }^{g}$ - zań czerwonych złotych sześćdziesiąt, rumak dropiaty $^{\mathrm{h}}$, rumak kary, bachmatek do pracy cisawy ${ }^{\mathrm{i}}$, koni gliniastych $\mathrm{cug}^{\mathrm{k}}$, koni szpakowatych ${ }^{1}$ cug.

Karoc - za nie dał nieboszczyk jegomości panu staroście ostrolenskiemu złotych sześćset, kolasa okowana, wóz skarbny okowany, namiot o trzech drągach - zań złotych pięćset.

Czaprak $^{\mathrm{m}}$ aksamitny hawtowany usarski, janczarek tureckich ${ }^{\mathrm{n}}$ dwie, szturmaków kołowych gwintowych ${ }^{\circ}$ dwa, muszkietów krzosowych gdańskich ${ }^{\mathrm{p}}$ dwa, fuzyji ${ }^{\mathrm{r}} \mathrm{dwie}$, innej strzelby siedmioro.

Prawa na Stupinie cum attinentis, prawa na Szatowie cum attinentis, prawa na Nagorzany, prawa na Boryszkowie, prawa na Paniowce, prawa na Malejowce,

a Pieniądze rogowe - rogowszczyzna, opłata pobierana przez dziedziców za prawo wypasu bydta rogatego na ich ziemiach.

b Złoty, złoty polski - jednostka obrachunkowa. Złoty polski po raz pierwszy został definiowany $w$ ordynacji menniczej $z 1528$ r., nie mając materialnego desygnatu, czyli nie zamierzano wybijać monet złotowych, ich wielokrotności, ani frakcji. Złotego wprowadzono jako odnośnik monetarny, wobec którego można było definiować wszystkie inne gatunki pieniądza. Wtedy powołano zasadnicza, zawsze niezmienna relacje 1 złp $=30 \mathrm{gr}$.

c Kary-maści czarnej w odcieniach wronim lub kruczym.

d Rumak-staropolska nazwa konia pochodzacego z Turcji; piękny, ognisty, rasowy wierzchowiec.

e Tarantowaty - maści siwej z nieregularnymi plamami różnej wielkości i barwy.

f Bachmat-staropolska nazwa niewielkiego, silnego, krępego i wytrzymałego konia tatarskiego.

g Gniady-maści brunatnej z grzywa, ogonem i dolnymi odcinkami kończyn czarnymi.

h Dropiaty - maści białej z małymi plamkami barwy czarnej, brunatnej lub rudej.

i Cisawy-(kasztanowaty), maści żółtawej, rudej, brązowej, niekiedy zbliżonej do brunatnej.

j Gliniasty - maści żółtawej, niekiedy z białą grzywą.

k Cug-zaprzęg składający się z sześciu lub czterech koni, zwykle jednej maści, zaprzężonych parami.

1 Szpakowaty - maści ciemnosiwej.

m Czaprak - podkładka pod siodło chroniąca grzbiet konia przed obtarciami, a siodło przed końskim potem.

n Janczarka - lekka strzelba turecka o długiej lufie i zakrzywionej kolbie; używana także $w$ Polsce w XVII-XVIII w.

- Szturmak - rodzaj hełmu lub strzelby; tu określenie strzelby z lufą gwintowana rozszerzona u wylotu (garłacz), i zamkiem kołowym (krzosowym).

p Muszkiet - ręczna broń palna piechoty z zamkiem lontowym (tu krzosowym czyli kołowym) stosowana od XVI do końca XVII w., podstawowe uzbrojenie oddziałów muszkieterskich piechoty i dragonii.

r Fuzyja-(fuzja) rodzaj długiej broni strzeleckiej z zamkiem skałkowym. 
prawa na Nowosiółki i przywileje od książąt Kuriatowiczów, prawa od jegomości pana Generała ${ }^{1}$ albo raczej assecuratia i inwentarze na Uchańkę i Kładniów.

Pieniądze za żyto na wyjeździe złotych tysiąc pięćset, pieniądze za pszono złotych dwieście, pieniądze za masło i za sery złotych dwieście.

Jakub Wołhodyiowski miecznik latyczowski manu propria.

\section{Bibliografia}

\section{Źródła drukowane}

Akta grodzkie i ziemskie z czasów Rzeczypospolitej Polskiej z archiwum tak zwanego bernardyńskiego we Lwowie..., t. 10, Spis oblat zawartych w aktach grodu i ziemstwa lwowskiego, oprac. O. Pietruski i X. Liske, Lwów 1884.

Groicki B., Obrona sierot $i$ wdów, wyd. J. Sawicki, Warszawa 1958.

Groicki B., Porządek sądów i spraw miejskich prawa majdeburskiego $w$ Koronie Polskiej, wyd. K. Koranyi, Warszawa 1953.

Makowiecki S., Relacyja Kamieńca wziętego przez Turków w roku 1672, oprac. P. Borek, Kraków 2008.

Pamiętnik Mikołaja Jemiołowskiego, towarzysza lekkiej choragwi, ziemianina województwa bełzkiego..., wyd. A. Bielowski, Lwów 1850.

\section{Literatura}

Borek P., Stolnik przemyski Jerzy Wołodyjowski w „Relacyi Kamieńca wziętego...”

Stanisława Makowieckiego i ostatniej części Trylogii Henryka Sienkiewicza, „Rocznik Przemyski”, t. 45, 2008, nr 3, s. 77-92.

Brückner A., Encyklopedia staropolska, t. 1-2, Warszawa 1939.

Ciesielski T., Spuścizny rodzinne $i$ archiwa majątkowo-gospodarcze polskiej szlachty w wybranych archiwach ukrainskich, [w:] Stan badań nad wielokulturowym dziedzictwem dawnej Rzeczypospolitej, t. 2, red. W. Walczak, K. Łopatecki, Białystok 2010, s. 291-305.

Czapliński W., Pan Wołodyjowski, [w:] Glosa do Trylogii, Białystok 1999, s. 99-109. Dr Antoni J. [Rolle J. A.], Państwo Wołodyjowscy, [w:] Sylwetki historyczne. Serya VIII, Kraków 1892, s. 296-343.

Dylewski A., Historia pieniądza na ziemiach polskich, Warszawa 2011.

\footnotetext{
1 Generał-Mikołaj Pot, generał ziem podolskich.
} 
Gadocha M., Testamenty i inwentarz Jadwigi i Marcina Mitkiewiczów - przyczynek do dziejów mieszczaństwa krakowskiego, „Rocznik Lubelskiego Towarzystwa Genealogicznego", t. 3, 2011, s. 98-121.

Gloger Z., Encyklopedia staropolska ilustrowana, t. 1-4, Warszawa 1900-1903.

Hundert Z., Garnizon wojskowy Kamieńca Podolskiego w latach 1667-1672 - zarys problematyki, „Saeculum Christianum”, t. 21, 2014, s. 141-153.

Instrukcja wydawnicza dla źródeł historycznych od XVI do połowy XIX wieku, red. K. Lepszy, Wrocław 1953.

Justyniarska-Chojak K., Taxatio rerum olim... - szesnastowieczne inwentarze pośmiertne $z$ ksiag miejskich województwa sandomierskiego, „Kwartalnik Historii Kultury Materialnej”, t. 63, 2015, nr 1, s. 41-54.

Justyniarska-Chojak K., Testamenty $i$ inwentarze pośmiertne z ksiagg miejskich województwa sandomierskiego (XVI-XVIII wiek), Kielce 2010.

Kijas J., Źródła historyczne „Pana Wołodyjowskiego”, „Pamiętnik Literacki”, R. 43, 1952, z. 3-4, s. 1137-1156.

Kizik E., Gdański inwentarz pośmiertny toruńskiego drukarza Johanna Christopha Jungmanna z 1778 roku, „Zapiski Historyczne”, t. 80, 2015, s. 169-178.

Klonder A., Mienie godne szlachcica i mieszczanina w krajach Europy Środkowej w XVII wieku, „Kwartalnik Historii Kultury Materialnej”, R. 49, 2001, nr 1-2, s. 81-94.

Klonder A., Wszystka spuścizna w Bogu spoczywajacego. Majątek ruchomy zwyklych mieszkańców Elblaga i Gdańska w XVII wieku, Warszawa 2000.

Kosman M., Państwo Wołodyjowscy, [w:] Na tropach bohaterów Trylogii, Warszawa 1986, s. 329-348.

Kwaśniewicz W., Encyklopedia dawnej broni i uzbrojenia ochronnego, Warszawa 2017.

Pielas J., Inwentarze pośmiertne ruchomości szlachty sandomierskiej z XVII-XVIII wieku - perspektywy i problemy metodologiczne przygotowywanej edycji źródłowej, „Kwartalnik Historii Kultury Materialnej”, t. 63, 2015, nr 4, s. 629-635.

Pośpiech A., Pułapka oczywistości. Pośmiertne spisy ruchomości szlachty wielkopolskiej z XVII wieku, Warszawa 1992.

Przyboś A., Hejking, [w:] Polski słownik biograficzny, t. 9, red. K. Lepszy, Wrocław 1961-1962, s. 351-352.

Sawicka Z., Słowniczek, [w:] Koń w życiu szlachty w XVI-XVIII w., Toruń 2004, s. 121-127.

Słownik języka polskiego, oprac. S. B. Linde, t. 1-4, Warszawa 1807-1814.

Słownik staropolski, red. K. Nitsch, S. Urbańczyk, t. 1-11, Warszawa 1953-1995.

Szymański J., Nauki pomocnicze historii, Warszawa 1983. 
Turnau I., Słownik ubiorów. Tkaniny, wyroby pozatkackie, skóry, broń i klejnoty oraz barwy znane w Polsce od średniowiecza do poczatku XIX w., Warszawa 1999.

Urzędnicy województwa ruskiego XIV-XVIII wieku (ziemie halicka, lwowska, przemyska, sanocka). Spisy, oprac. K. Przyboś, Wrocław 1987.

Wagner M., Wołodyjowski Jerzy, [w:] Słownik biograficzny oficerów polskich drugiej połowy XVII wieku, Oświęcim 2013, s. 296.

Życiński S., Inwentarz pozostałości po Jerzym Wołhodyjowskim pułkowniku choragwi laudańskiej $z$ roku 1672, „Zeszyty Naukowe Muzeum Wojska w Białymstoku", 1998, z. 12, s. 159-161. 